\title{
Development, characterization and evaluation of the dissolution profile of sulfasalazine suspensions
}

\author{
Mayre Aparecida Borges da Costa, Ana Lucia Vazquez Villa, Rita de Cássia da Silva Ascenção \\ Barros, Eduardo Ricci-Júnior*, Elisabete Pereira dos Santos
}

School of Pharmacy, Federal University of Rio de Janeiro, Rio de Janeiro, RJ, Brazil

\begin{abstract}
This paper reports the development, characterization and in vitro dissolution behavior of sulfasalazine suspensions for treatment of chronic intestinal inflammatory diseases. Three formulations were developed, from powdered sulfasalazine obtained from different suppliers. The sulfasalazine was characterized regarding concentration, Fourier Transform Infrared Spectroscopy (FTIR), Differential Scanning Calorimetry (DSC), X-Ray Diffraction (XRD), particle size distribution, polydispersion and solubility. The suspensions were developed and characterized regarding $\mathrm{pH}$, viscosity, density, particle size, sedimentation volume, concentration and dissolution. The $\mathrm{pH}$ values were slightly acidic. The method of preparing the suspensions reduced the particle sizes and made the size distribution more homogeneous. The dissolution studies showed that the sulfasalazine suspensions had low solubility in acidic media, but dissolve quickly, reaching levels of $85 \%$, in neutral media or media containing $0.5 \%$ of surfactants such as polysorbate 80 . Besides this, the sulfasalazine suspensions were classified as having immediate dissolution because they reached dissolution levels near 100\% in 20 minutes.
\end{abstract}

Uniterms: Sulfasalazine/suspensions/dissolution. Chronic intestinal inflammatory diseases/treatment.

O trabalho reporta o desenvolvimento, caracterização e estudo in vitro de dissolução de suspensões de sulfassalazina para uso em doenças inflamatórias crônicas intestinais. Desenvolveram-se três formulações baseadas em fornecedores diferentes de pó de sulfassalazina. A sulfassalazina foi caracterizada quanto a Teor, Infravermelho por Transformada de Fourier (FTIR), Calorimetria Diferencial de Varredura (DSC), Difração de Raios-X (XRD), distribuição de tamanho das partículas, índice de polidispersão e solubilidade. A suspensão foi desenvolvida e caracterizada quanto a $\mathrm{pH}$, viscosidade, densidade, tamanho de partícula, volume de sedimentação, teor e estudo de dissolução. Os valores de $\mathrm{pH}$ determinados foram levemente ácidos. O método de preparo das suspensões reduziu o tamanho das partículas e tornou a distribuição de tamanho mais homogênea. Os estudos de dissolução mostraram que a suspensão de sulfassalazina tem problemas de solubilidade em meios de caráter ácido, entretanto, sofre dissolução rápida acima de $85 \%$ em meios neutros ou contendo $0,5 \%$ de tensoativos como Polissobato 80 . Além disso, as suspensões de sulfassalazina foram classificadas como formulações de dissolução imediata porque a partir de 20 minutos sofrem dissolução em torno de $100 \%$.

Unitermos: Sulfassalazina/suspensões/dissolução. Doenças inflamatórias crônicas intestinais/tratamento.

\section{INTRODUCTION}

Sulfasalazine (SSZ) is widely used to treat ulcerative colitis and Crohn's disease. Ulcerative colitis is caused by

\footnotetext{
*Correspondence: E. Ricci-Júnior. Laboratório de Desenvolvimento Galênico (LADEG). Faculdade de Farmácia. Centro de Ciências da Saúde. Universidade Federal do Rio de Janeiro (UFRJ). Avenida Carlos Chagas Filho s/n - Bloco L, 21941-902 - Rio de Janeiro, RJ - Brasil. E-mail: ricci@pharma.ufrj.br
}

inflammation of the large intestine, colon and/or rectum, while Crohn's disease causes chronic inflammation, mainly in the lower part of the small intestine. SSZ is also used to treat rheumatoid arthritis and ankylosing spondylitis, which are the main rheumatic and autoimmune diseases in the world (Trinches et al., 2004; Genc et al., 2007).

SSZ is formed by the combination of 5-aminosalicylic acid (5-ASA) with sulfapyridine (SP) through an azo bond. 5-ASA also has antiinflammatory action. When 
administered orally, $30 \%$ of the SSZ is absorbed in the upper part of the gastrointestinal tract and the remainder passes to the colon, where the azo bond is broken down by the action of bacterial azoreductase enzymes, releasing the 5-ASA to act in the colon. The SP is totally absorbed and metabolized to $\mathrm{N}$-acetyl sulfapyridine by hepatic enzymes (Kumagai et al., 2004). Both SSZ and SP have a variety of actions, such as immunomodulation, antibacterial activity and inhibition of folate-dependent enzymes (Kumagai et al., 2004).

According to the biopharmaceutical classification, SSZ is a class IV drug (Clarysse et al., 2011), insoluble in water and with low permeability. SSZ has acidic character due to three different groups - carboxyl, sulfonamide and phenolic hydroxyl - making it soluble in alkaline media and insoluble in acidic media. Trinches et al. (2004) showed that the bioavailability of SSZ is the same if administered in tablet or suspension form. However, in many countries, like Brazil, the drug is not available in suspension form, even though elderly and very young patients have trouble swallowing tablets. Grinding tablets into powder and addition to a liquid carrier can leave particles capable of clogging the catheters of bedridden patients receiving medicines by this route. Therefore, SSZ in suspension is the best method of administration in newborns, young children, and the elderly. Besides more flexible administration, the dosage of the liquid formulation can be adjusted more easily (Trinches et al., 2004).

The objective of this study was the preparation, physical and chemical characterization and assessment of the dissolution profile in vitro of oral suspensions of SSZ $250 \mathrm{mg} / 5 \mathrm{~mL}$. The dissolution data of the suspension and the reference tablet (Azulfin ${ }^{\circledR}$ ) were compared to evaluate the advantages of the liquid suspension in relation to the solid form.

\section{MATERIAL AND METHODS}

\section{Material}

The SSZ used as reference was obtained from Sigma (Fluka, lot 1450407, $10 \mathrm{~g}$, concentration 98.3\%). To prepare the formulations, sulfasalazine (SSZ) was acquired from three suppliers: SSZ-P of the KX (China), SSZ-D of the KZC (China), and SSZ-H of the SH (China). Sodium hydroxide, glacial acetic acid, acetic acid, phosphoric acid, monobasic potassium phosphate, sodium chloride and polysorbate 80 (Tween $\left.{ }^{\circledR}\right)$, all PA grade, were obtained from Vetec (Brazil). Methanol, ethanol, acetonitrile, HPLC grade, were obtained from Tédia Brazil
(Brazil). Sodium cyclamate, sodium benzoate and sodium carboxymethylcellulose were acquired from Pharma Special (Brazil). Orange essential oil was purchased from Dierberger (Brazil).

\section{Characterization of the SSZ samples}

The method to determine the sulfasalazine content was that described in the United States Pharmacopoeia (34th edition). This method consists of spectrophotometry of the sample dissolved in a sodium hydroxide $0.1 \mathrm{~N}$ solution. The standard used was that obtained from Sigma (concentration $\geq 98 \%$ ). A $150 \mathrm{mg}$ sample of SSZ was weighed and transferred to a $100 \mathrm{~mL}$ amber round bottom beaker. The sodium hydroxide $0.1 \mathrm{~N}$ solution was added to the beaker to dissolve the SSZ. An aliquot of $1 \mathrm{~mL}$ was then transferred to a $200 \mathrm{~mL}$ round-bottom beaker containing $4 \mathrm{~mL}$ of the acetic acid $0.1 \mathrm{~N}$ solution and the volume was completed with water. From this solution a $5 \mathrm{~mL}$ aliquot was withdrawn and the volume was completed with water to $10 \mathrm{~mL}$. The sample was read at $359 \mathrm{~nm}$ to obtain an absorbance of 0.5 . This procedure was carried out in triplicate.

Tablets of SSZ in potassium bromate $(\mathrm{KBr})$ were prepared at $1 \%(\mathrm{w} / \mathrm{w})$ with the standard SSZ and the three samples (SSZ-P, SSZ-D and SSZ-H). The spectra were generated by a Shimadzu Prestige 21 infrared spectrophotometer (Japan) in a wavelength range of 400 to $3800 \mathrm{~cm}^{-1}$

The X-ray diffractograms of the samples were obtained with a Rigaku Miniflex X-ray diffractometer (Japan), operating at $40.0 \mathrm{kV}$ and $30.0 \mathrm{~mA}$, with $2 \theta$ diffraction angles from 2 to $60^{\circ}$ at room temperature $\left(28 \pm 2{ }^{\circ} \mathrm{C}\right)$, with $\mathrm{Cu}-\mathrm{K} \theta$ radiation $(\lambda=1.542$ Angstroms $)$ and scanning speed of $0.05^{\circ} / \mathrm{s}$.

The DSC curves of the samples were obtained with a Shimadzu DSC 60 apparatus (Japan), under a dynamic nitrogen atmosphere $(50 \mathrm{~mL} / \mathrm{min})$ and heating rate of $15^{\circ} \mathrm{C} / \mathrm{min}$, in a temperature range from 35 to $500{ }^{\circ} \mathrm{C}$, in partially closed aluminum crucibles. The mass of the samples was $3 \mathrm{mg}$. The calorimeter was calibrated using metallic indium and zinc standards.

The particle size distribution and polydispersity were measured with a Malvern Mastersizer 2000/2000E particle size analyzer(United Kingdom) using the Hydro 2000 SM module for liquid samples. Since the best dispersant medium for reading the size of particles in suspension is a medium in which the drug is insoluble, we used water as the dispersant. This device uses laser diffraction and the particle diameter was obtained when the light passes through the suspension containing the 
particles and is diffracted to a determined angle, to obtain the distribution. Average particle size was expressed as the volume mean diameter $\left(\mathrm{D}_{4.3}\right)$ and polydispersity was given by span index. The span index can be calculated by the following equation:

$$
\text { Span Index }=\left(\mathrm{D}_{0.9}-\mathrm{D}_{0.1}\right) / \mathrm{D}_{0.5}
$$

where $\mathrm{D}_{0.9}$ is a diameter when $90 \%$ of the volume distribution is below this value; $\mathrm{D}_{0.1}$ is a diameter when $10 \%$ of the volume distribution is below this value, and $\mathrm{D}_{0.5}$ is the diameter where $50 \%$ of the distribution is above and $50 \%$ is below. Span is a useful statistical parameter to assess the quality of a particle size distribution, which can be monodispersed or polydispersed (Skoog; Holler; Crouch, 2007).

\section{Production and characterization of the SSZ suspension}

The oral suspension of SSZ was produced using raw material from the three suppliers identified earlier: SSZ-P, SSZ-D and SSZ-H. The sulfasalazine suspensions were produced at a concentration of $50 \mathrm{mg} / \mathrm{mL}$ according to Figure 1. The formulations are described in Table I.

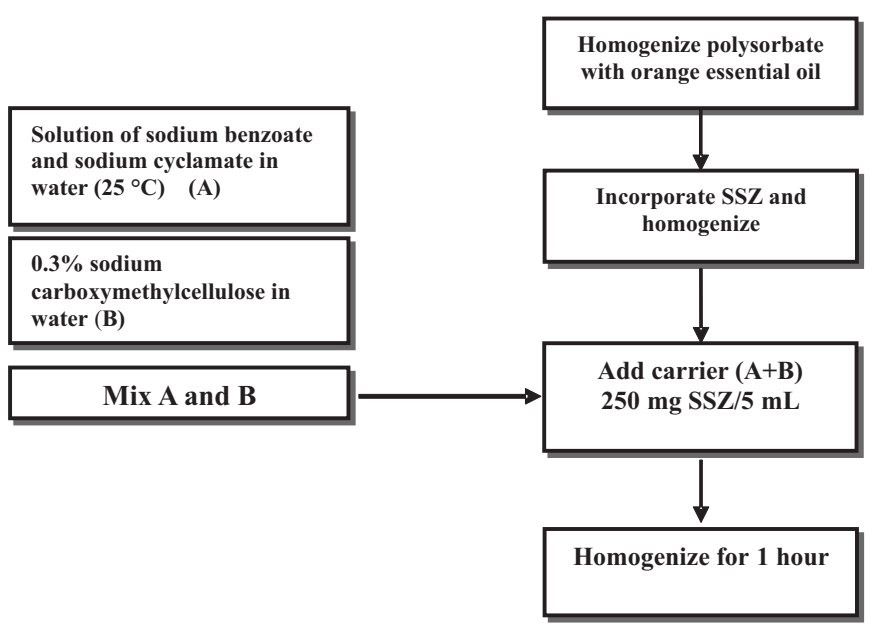

FIGURE 1 - Flow chart for preparation of the SSZ suspensions.

The suspensions' density was determined using a 25-mL pycnometer. The $\mathrm{pH}$ was determined using a Mettler Toledo potentiometer previously calibrated with 4.0 and 7.0 buffers. All the readings were taken at room temperature $\left(25 \pm 2{ }^{\circ} \mathrm{C}\right)$.

The sedimentation rates were measured to assess the degree of redispersion of the suspension. The samples were transferred to $100 \mathrm{~mL}$ test tubes, considering the initial height $\left(\mathrm{H}_{0}\right)$ to be 100 . The height of the sediment
TABLE I - Sulfasalazine suspension formulations

\begin{tabular}{lc}
\hline Formulation & Quantity (g) \\
\hline Sulfasalazine & 5.0 \\
Sodium cyclamate & 0.01 \\
Sodium benzoate & 0.5 \\
Sodium carboxymethylcellulose & 0.3 \\
Polysorbate 80 & 0.5 \\
Orange essential oil & 0.2 \\
Water (sufficient quantity for) & $100 \mathrm{~mL}$ \\
\hline
\end{tabular}

(Ht) was measured from 6 to 192 hours. The $\mathrm{H}_{\mathrm{t}} / \mathrm{H}_{0}$ ratio was used to calculate the sedimentation rate (Prista; Alves; Morgado, 2008).

The particle size distribution and Span of the suspensions were measured in a Malvern Mastersizer particle size analyzer $(2000 / 2000 \mathrm{E}, \mathrm{UK})$ using water as the diluent medium. Average particle size was expressed as the volume mean diameter $\left(\mathrm{D}_{4.3}\right)$ and polydispersity was given by span index. The span index can be calculated by the following equation:

$$
\text { Span Index }=\left(\mathrm{D}_{0.9}-\mathrm{D}_{0.1}\right) / \mathrm{D}_{0.5}
$$

where $\mathrm{D}_{0.9}$ is a diameter when $90 \%$ of the volume distribution is below this value; $\mathrm{D}_{0.1}$ is a diameter when $10 \%$ of the volume distribution is below this value, and $\mathrm{D}_{0.5}$ is the diameter where $50 \%$ of the distribution is above and $50 \%$ is below. Span is a useful statistical parameter to assess the quality of a particle size distribution.

The zeta potential of the samples was determined employing a Malvern Zetasizer (UK). $0.3 \mathrm{ml}$ of the suspension was added into a volumetric flask with capacity of $10 \mathrm{~mL}$. The volume was completed with ultrapure water. The samples was gently homogenized. The refractive index and the absorbance at $766 \mathrm{~nm}$ were measured for each sample and the data recorded on the equipment's software. The measurements were performed in microelectrophoretic cell. The samples were gently added to the cells to avoid the formation of bubbles. Six readings for each sample were performed. Results were expressed as mean and standard deviation.

The viscosity of the suspensions was determined in a Brookfield viscometer (LVT) using a needle 2 and velocity of $30 \mathrm{rpm}$. Six determinations for each sample were performed at room temperature $\left(28^{\circ} \mathrm{C}\right)$.

The SSZ concentration was determined by highperformance liquid chromatography (HPLC). The experimental conditions were those suggested by Costa et al. (2012). An aliquot of the suspension was placed in a 
round bottom beaker and dissolved with acetonitrile and water (1:1). After dissolution, the solution was filtered through a Millex ${ }^{\circledR}$ membrane $(0.45 \mu \mathrm{m})$ before analysis.

\section{Solubility and dissolution study}

Solubility is one of the most important parameters in pre-formulation studies (Milani-Zakeri et al., 2009; Clarysse et al., 2011). It was determined by adding an excess of SSZ in $50 \mathrm{~mL}$ of a dissolution medium. The solubility was tested in the following dissolution media: gastric juice ( $\mathrm{HCl} 0.1 \mathrm{~N} \mathrm{pH} \mathrm{1.2),} \mathrm{phosphate} \mathrm{buffer} \mathrm{pH}$ 5.8 (USP, 2011a), phosphate buffer pH 5.8 with $0.5 \%$ polysorbate 80, phosphate buffer pH 6.8 (USP, 2011a), and phosphate buffer $\mathrm{pH} 7.4$ (USP, 2011a). The SSZ samples were placed in a magnetic stirrer operating at $100 \mathrm{rpm}$, at room temperature $\left(25^{\circ} \mathrm{C} \pm 2{ }^{\circ} \mathrm{C}\right)$ for $24 \mathrm{~h}$. The samples were centrifuged for $120 \mathrm{~min}$ at $4000 \mathrm{rpm}$ for separation of the supernatant. The process was performed in triplicate. The SSZ concentration in the supernatant was determined by the spectrophotometric method described by Costa et al. (2012). The SSZ was dissolved in $\mathrm{NaOH} 0.1 \mathrm{M}$, diluted to obtain the analytic curve in the range from 2 to $12 \mu \mathrm{g} /$ $\mathrm{mL}$. The absorbances of the solutions in aqueous and acid media were measured at 359 and $456 \mathrm{~nm}$, respectively. The linearity, selectivity, precision, accuracy and robustness were evaluated according the criteria described by Costa et al. (2012).

The solubility values of the SSZ in the dissolution media were used to establish the sink conditions. In the dissolution testing was used a dissolution equipment DTR6 (Erweka). The samples were weighed and transferred to vessels containing $900 \mathrm{~mL}$ of dissolution medium. Due to the specific activity of SSZ in the colon and the physiological characteristics of the gastrointestinal system, we selected five media: $\mathrm{HCl} 0.1 \mathrm{~N} \mathrm{pH} \mathrm{1.2;} \mathrm{phosphate}$ buffer $\mathrm{pH} 5.8$, phosphate buffer $\mathrm{pH} 5.8$ with $0.5 \%$ polysorbate 80 ; phosphate buffer $\mathrm{pH} 6.8$; and phosphate buffer $\mathrm{pH}$ 7.4. The dissolution tests were performed using USP apparatus 2 (Hanson, Gray, 2004). Rotations of 25 and $50 \mathrm{rpm}$ were tested in the dissolution testing of the suspensions (Siewert et al., 2003; Hanson, Gray, 2004). The temperature was maintained at $37 \pm 0.5^{\circ} \mathrm{C}$. Dissolution equipment DTR6 (Erweka) was used in the dissolution assays. $10 \mathrm{~mL}$ were collected at pre-established times. After sampling and filtration, the samples were diluted in each medium. The SSZ concentration was measured using the spectrophotometric method described by Costa et al. (2012). The method was selective, linear of 2 to $12 \mu \mathrm{g} / \mathrm{mL}(\mathrm{R}=0.999)$, precise ( $\mathrm{DPR}=2.7 \%)$, accurate $(99.7 \pm 1.3 \%)$ and robust according to Costa et al. (2012).
The percentage of dissolved SSZ was calculated according to the total quantity of SSZ suspension added in the basin. The dissolution profile was obtained from the percentage of SSZ dissolved as a function of time.

The Azulfin ${ }^{\circledR}$ tablet presents gastro-resistant coating. Thus, the dissolution testing was measured in two stages (USP, 2011b). The tablets were transferred to $900 \mathrm{~mL}$ of gastric juice $(\mathrm{HCl} 0.1 \mathrm{~N}, \mathrm{pH} 1.2)$, temperature of $37 \pm 0.5^{\circ} \mathrm{C}$, and stirring by paddle (Apparatus 2 ) at rotation speed of $100 \mathrm{rpm}$ for 2 hours. In the second stage, the tablets were added to $900 \mathrm{~mL}$ of phosphate buffered saline, $\mathrm{pH} 7.4$, temperature of $37 \pm 0.5^{\circ} \mathrm{C}$, and stirring by paddle at rotation speed of $100 \mathrm{rpm}$ for 2 hours.

The dissolution data of the oral liquid suspension and tablet were compared to evaluate the advantages of the liquid in relation to the solid form.

The Graph Pad Prism software, version 5.04 (19922010 Graph Pad Software, Inc.) was used to evaluate significant differences of the dissolved percentages between the SSZ-D, SSZ-H and SSZ-P formulations in each dissolution medium evaluated. The dissolution profiles were compared using two-way ANOVA, whereby the percentage dissolved was the dependent variable and time interval was the repeated factor. A p-value lower than 0.05 was considered statistically significant.

\section{RESULTS AND DISCUSSION}

The mean concentrations and relative standard deviations (RSD) of the samples SSZ-D, SSZ-H and SSZ-P were $99.7 \pm 0.41,100.3 \pm 0.38$ and $99.2 \pm 0.65 \%$, respectively. These SSZ concentrations are within the range of acceptable limits of 98.5 to $100.5 \%$ recommended by the USP $34^{\text {th }}$ edition (2011b). The RSD values were also satisfactory, below the level of $2 \%$ recommended by the same source.

The FTIR spectra of the samples and the standard substance (Table II) were similar, with presence of the bands mentioned in the literature (Moffat, Osselton, Widdop, 2004). There was a pronounced band at $768 \mathrm{~cm}^{-1}$, referring to the vibration of the $\mathrm{C}-\mathrm{H}$ bond of the aromatic ring, bands at $1082 \mathrm{~cm}^{-1}, 1128 \mathrm{~cm}^{-1}$ and $1173 \mathrm{~cm}^{-1}$, referring to $\mathrm{C}-\mathrm{O}$ deformations characteristic of stretching of the $\mathrm{C}=\mathrm{O}$ and $\mathrm{C}=\mathrm{N}$ bonds, and deformation of the $\mathrm{N}-\mathrm{H}$ bond. In the region between 3400 and $3450 \mathrm{~cm}^{-1}$, there were bands characteristic of stretching of the oxygen-hydrogen bond referring to the phenolic group and carboxylic acid group.

The XRD results for the samples SSZ-H, SSZ-P and SSZ-D showed that the substances have XRD profile similar to that of the standard substance (Sigma) 
TABLE II - FTIR results of samples SSZ-P, SSZ-D, SSZ-H and Sigma standard

\begin{tabular}{lccc}
\hline \multirow{2}{*}{ Standard } & \multicolumn{3}{c}{$\lambda \mathbf{m a x}\left(\mathbf{c m}^{-\mathbf{1}}\right)$} \\
\cline { 2 - 4 } & SSZ-D & SSZ-H & SSZ-P \\
\hline 768 & 767 & 766 & 767 \\
1082 & 1081 & 1082 & 1083 \\
1128 & 1128 & 1128 & 1126 \\
1173 & 1171 & 1172 & 1172 \\
1637 & 1635 & 1636 & 1637 \\
1676 & 1676 & 1675 & 1677 \\
\hline
\end{tabular}

(Figure 2), with well-defined crystalline structure and characteristic signals at $11.9^{\circ}, 15.1^{\circ}, 24.1^{\circ}$ and $27.6^{\circ}$. However, a variation can be seen in the intensity of the peaks for the substances obtained from suppliers $\mathrm{H}$ and $\mathrm{D}$ at $24.1^{\circ}$. The alteration in the intensity of the peaks can be related to the organizational structure of the crystals.

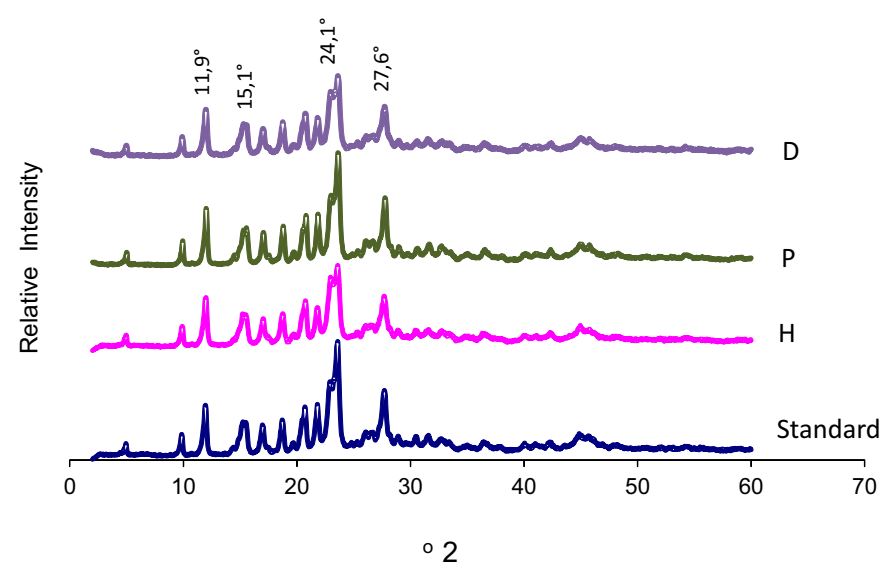

FIGURE 2 - Diffractograms of SSZ: Sigma standard, sample P, sample $\mathrm{H}$ and sample D.

Figure 3 shows the DSC curves obtained with the three samples and the standard SSZ. The endothermic peak refers to the melting of the samples, which occurred

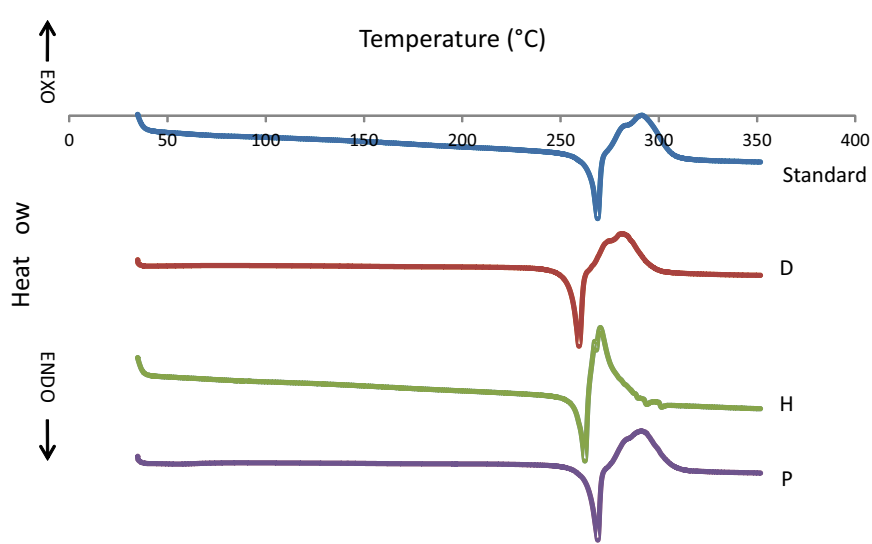

FIGURE 3 - DSC curves of SSZ: Sigma standard, sample P, sample $\mathrm{H}$ and sample D.

at $259.88^{\circ} \mathrm{C}$ for the Sigma standard and $259.34{ }^{\circ} \mathrm{C}$, $260.17^{\circ} \mathrm{C}$ and $259.56{ }^{\circ} \mathrm{C}$ for the samples from suppliers $\mathrm{D}$, $\mathrm{H}$ and $\mathrm{P}$, respectively. At this stage, the sample passes from a rigid state to a more flexible structure, characteristic of an endothermic event, and its mobility allows alleviating the strain. No other event was observed at a different temperature in the DSC curves of the samples from the three suppliers, indicating the existence of sulfasalazine without polymorphism. The next event is a peak resulting from the sample's decomposition.

The results show that the solubility of SSZ increases with increasing $\mathrm{pH}$ of the medium due to its acidic character (Table III). The solubility values in hydrochloric acid $0.1 \mathrm{~N}$ were low. The use of the surfactant increased the SSZ's solubility. There were also differences in solubility of samples D, H and P. This difference shows that the lots from the three suppliers have different characteristics. As the $\mathrm{pH}$ of the media increases, becoming more basic, the solubility increases due to the acidic character of SSZ. The increase of $\mathrm{pH}$ causes a shift of the equilibrium point, increasing the ionized form of SSZ, as indicated by the strong yellow color at $\mathrm{pH}$ 7.4. In this case, a bathochromic shift occurs in the wavelength of maximum absorption, from 359 to $456 \mathrm{~nm}$ (Table III).

TABLE III - Solubility values $(\mathrm{mg} / \mathrm{mL})$ of the samples of SSZ from suppliers D, H and P measured by UV/Vis spectrophotometry at $25^{\circ} \mathrm{C}\left( \pm 2{ }^{\circ} \mathrm{C}\right)$

\begin{tabular}{lcccc}
\hline Medium & $\lambda(\mathbf{n m})$ & D & H & P \\
\hline HCl 0.1 N pH 1.2 & 359 & $0.018 \pm 0.002$ & $0.021 \pm 0.002$ & $0.023 \pm 0.003$ \\
Phosphate buffer (pH 5.8) & 359 & $0.299 \pm 0.045$ & $0.154 \pm 0.008$ & $0.367 \pm 0.029$ \\
Phosphate buffer (pH 5.8) with 0.5\% polysorbate 80 & 359 & $0.739 \pm 0.059$ & $0.757 \pm 0.044$ & $0.679 \pm 0.031$ \\
Enteric juice (pH 6.8) & 359 & $2.759 \pm 0.206$ & $2.080 \pm 0.050$ & $1.509 \pm 0.425$ \\
Phosphate buffer saline (pH 7.4) & 456 & $6.890 \pm 0.059$ & $4.030 \pm 0.090$ & $5.306 \pm 0.649$ \\
\hline
\end{tabular}

Mean \pm Standard Deviation of $\mathrm{n}=6$ determinations 
TABLE IV - Parameters considered in the characterization of the raw materials and the $250 \mathrm{mg} / 5 \mathrm{~mL}$ sulfasalazine suspension

\begin{tabular}{lcccccc}
\hline \multirow{2}{*}{ Distribution } & \multicolumn{3}{c}{ Particle size of raw materials $(\boldsymbol{\mu m})$} & \multicolumn{3}{c}{ Particle size of the suspension $(\boldsymbol{\mu m})$} \\
\cline { 2 - 7 } & $\mathbf{D}$ & $\mathbf{H}$ & $\mathbf{P}$ & SD & SH & SP \\
\hline $\mathrm{D}_{50}$ & 4.94 & 6.68 & 4.67 & 2.92 & 2.30 & 3.97 \\
$\mathrm{D}_{10}$ & 1.13 & 1.28 & 1.12 & 0.96 & 0.94 & 1.41 \\
$\mathrm{D}_{90}$ & 33.05 & 89.51 & 69.03 & 12.27 & 6.43 & 11.74 \\
Span & 32.82 & 89.32 & 14.54 & 3.87 & 2.38 & 2.60 \\
Zeta potential* & & & & $-39.15 \pm 2.25$ & $-47.83 \pm 1.04$ & $-46.03 \pm 2.86$ \\
\hline
\end{tabular}

Mean of $\mathrm{n}=3$ determinations. *Mean and standard deviation of $\mathrm{n}=3$ determinations

Table IV shows the particle size distribution of samples D, P and H and the SSZ suspensions. The three SSZ samples all had large particles with high span values, indicating wide size distribution, classifying them as polydispersed. The sizes of the particles in suspension were smaller and the size distribution was narrower, as indicated by the span values. The suspension produced with sample $\mathrm{H}$ had the smallest average particle size among the suspensions. All the samples presented negative zeta potential values. The negative charge can help stabilize the suspension due to the repulsive force between the particles. This negative charge of the particles is due to the ionization of the carboxylic acid group of the SSZ molecule.

The density, $\mathrm{pH}$ and viscosity values of the suspensions SSZ-D, SSZ-H and SSZ-P are shown in Table V. The suspensions' density was similar to that of water, while the $\mathrm{pH}$ was slightly acidic due to the acidic character of SSZ. The viscosity was similar among the formulations.

We monitored the sedimentation volume for 192 hours to assess the flocculation degree. After 12 hours the three suspensions presented sedimentation volume
TABLE V - Values of $\mathrm{pH}$, density and viscosity of SSZ $250 \mathrm{mg} / 5 \mathrm{~mL}$ from three suppliers (D, H and P)

\begin{tabular}{lccc}
\hline Parameters & SSZ-D & SSZ-H & SSZ-P \\
\hline Density $(\mathrm{g} / \mathrm{mL})$ & 1.0205 & 1.0185 & 1.0218 \\
$\mathrm{pH}$ & 5.25 & 5.32 & 5.20 \\
Viscosity $(\mathrm{cPs})$ & 70 & 70 & 75 \\
\hline
\end{tabular}

Mean of $\mathrm{n}=3$ determinations

values (F) near 1, while after 192 hours the suspensions presented values below 0.35 and slow sedimentation speeds, classifying them as deflocculated. However, when shaken for 1 minute they presented good redispersion, without caking.

According to the RSD values shown in Table VI, in all cases after homogenization for 1 minute, the suspensions presented RSD values lower than $2.0 \%$, below the acceptance criterion for homogeneity (USP, , 2011b). Considering a variation in the sulfasalazinecontent of $\pm 10 \%$, the limit should be between 45.0 and $55.0 \mathrm{mg} / \mathrm{mL}$. All the suspensions remained within this interval.

TABLE VI - SSZ concentrations found in suspensions D, H and P by the spectrophotometric method

\begin{tabular}{|c|c|c|c|c|c|c|c|c|}
\hline \multirow{2}{*}{\multicolumn{2}{|c|}{ Sample Suspension }} & \multicolumn{3}{|c|}{ Morning (9:00 h) } & \multicolumn{3}{|c|}{ Afternoon (15:00 h) } & \multirow{2}{*}{$\begin{array}{c}\text { Final Mean } \\
(\mathrm{mg} / \mathrm{mL})\end{array}$} \\
\hline & & $\mathrm{mg} / \mathrm{mL}$ & Mean & RSD (\%) & $\mathrm{mg} / \mathrm{mL}$ & Mean & RSD (\%) & \\
\hline & Top & 48.34 & & & 46.54 & & & \\
\hline \multirow[t]{3}{*}{ D } & Middle & 48.01 & 48.3 & 0.52 & 46.54 & 46.7 & 0.52 & 47.5 \\
\hline & Bottom & 48.50 & & & 46.96 & & & \\
\hline & Top & 49.30 & & & 47.89 & & & \\
\hline \multirow[t]{3}{*}{$\mathbf{H}$} & Middle & 49.22 & 48.8 & 1.74 & 48.22 & 48.3 & 0.91 & 48.5 \\
\hline & Bottom & 47.79 & & & 48.76 & & & \\
\hline & Top & 52.60 & & & 53.39 & & & \\
\hline \multirow[t]{2}{*}{$\mathbf{P}$} & Middle & 53.64 & 53.5 & 1.63 & 53.09 & 53.1 & 0.46 & 53.3 \\
\hline & Bottom & 54.34 & & & 52.90 & & & \\
\hline
\end{tabular}

RSD- Relative Standard Deviation 
The sink conditions were not satisfied in the simulated gastric juice ( $\mathrm{HCl} 0.1 \mathrm{~N}, \mathrm{pH} 1.2$ ), because SSZ has low solubility in acidic media. Thus, others media were chosen to attain sink conditions. Figure 4 shows the dissolution profiles of the suspensions in the acidic medium. In this medium, the SSZ particles remained virtually insoluble. The samples were collected during a period of 120 minutes and the quantity of dissolved SSZ was measured. Rotation of $25 \mathrm{rpm}$ (Figure 4A) was not sufficient for the study due to the high standard deviations caused by the insolubility of the drug in the medium. This rotation speed was not able to homogenize the suspension of SSZ particles in the receiving medium. On the other hand, the speed of $50 \mathrm{rpm}$ (Figure 4B) was adequate for the dissolution study in the acidic medium, in which $10 \%$ of the drug was dissolved after $120 \mathrm{~min}$. However, the suspension produced with sample SSZ-P did not reach $10 \%$ dissolution as it did for the other samples (SSZ-D and SSZ-H). Besides this, sink conditions were not attained in the dissolution study due to the low solubility of the drug in acidic media, which causes saturation of the medium and hampers determination of the dissolution profile (Hanson; Gray, 2004).

The dissolution profiles of the suspensions in phosphate buffer are shown in Figures 5, 6, 7 and 8.
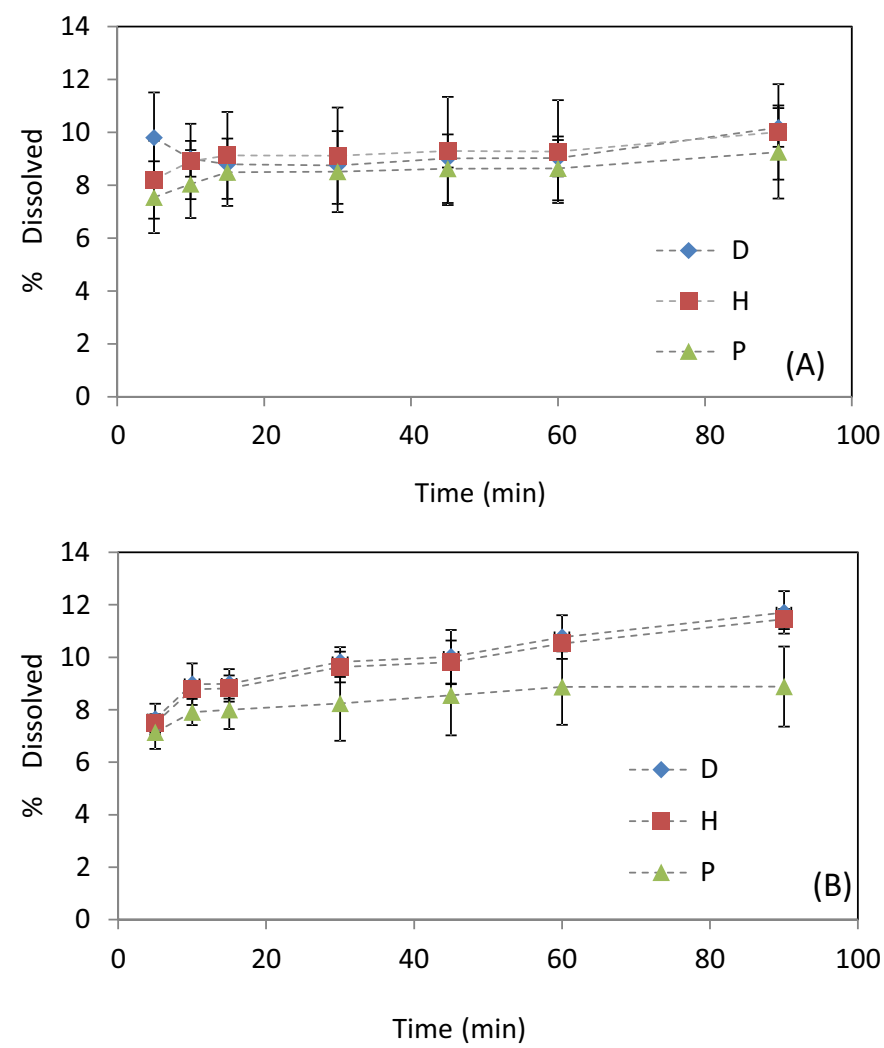

FIGURE 4 - Dissolution profiles of suspensions of SSZ (250 $\mathrm{mg} / 5 \mathrm{~mL}$ ) in $\mathrm{HCl} 0.1 \mathrm{~N} \mathrm{pH} \mathrm{1.2,} \mathrm{at} 25 \mathrm{rpm}(\mathrm{A})$ and $50 \mathrm{rpm}(\mathrm{B})$. Mean and standard deviation of $\mathrm{n}=6$ determinations.
The results of the two-way Anova for the phosphate buffer pH 5.8 medium at $25 \mathrm{rpm}$ (Figure $5 \mathrm{~A}$ ) show there was a significant difference in the dissolved percentage $(\mathrm{P}<0.05)$ between formulations $\mathrm{D}$ and $\mathrm{H}$ at each time interval, with the exception of 90 minutes, and between $\mathrm{D}$ and $\mathrm{P}$ for all dissolution times. The results also show that formulation $\mathrm{D}$ had a different dissolution profile than suspensions $\mathrm{P}$ and $\mathrm{H}$. Between formulations $\mathrm{H}$ and $\mathrm{P}$, in phosphate buffer $\mathrm{pH} 5.8$ and velocity of $25 \mathrm{rpm}$, there was no significant difference $(\mathrm{P}>0.05)$ between the profiles. After 15 minutes, formulation P presented a dissolved percentage of $100.14 \%$ while the figure for formulation $\mathrm{H}$ was $96.53 \%$ (Figure $5 \mathrm{~A})$. In the phosphate buffer $\mathrm{pH} 5.8$ dissolution medium at rotation of $50 \mathrm{rpm}$, no significant differences $(\mathrm{P}>0.05)$ were observed for any of the formulations. At a rotation speed $50 \mathrm{rpm}$ (Figure 5B), the drug dissolved completely after 15 minutes for formulations $\mathrm{P}(101.88 \%)$ and $\mathrm{H}(99.13 \%)$. However, the suspension produced with sample SSZ-D showed dissolution of $90.16 \%$ with high standard deviations (Figure 5B).

The dissolution behavior of formulations $\mathrm{D}, \mathrm{H}$ and $\mathrm{P}$ in the phosphate buffer $\mathrm{pH} 5.8$ medium with $0.5 \%$
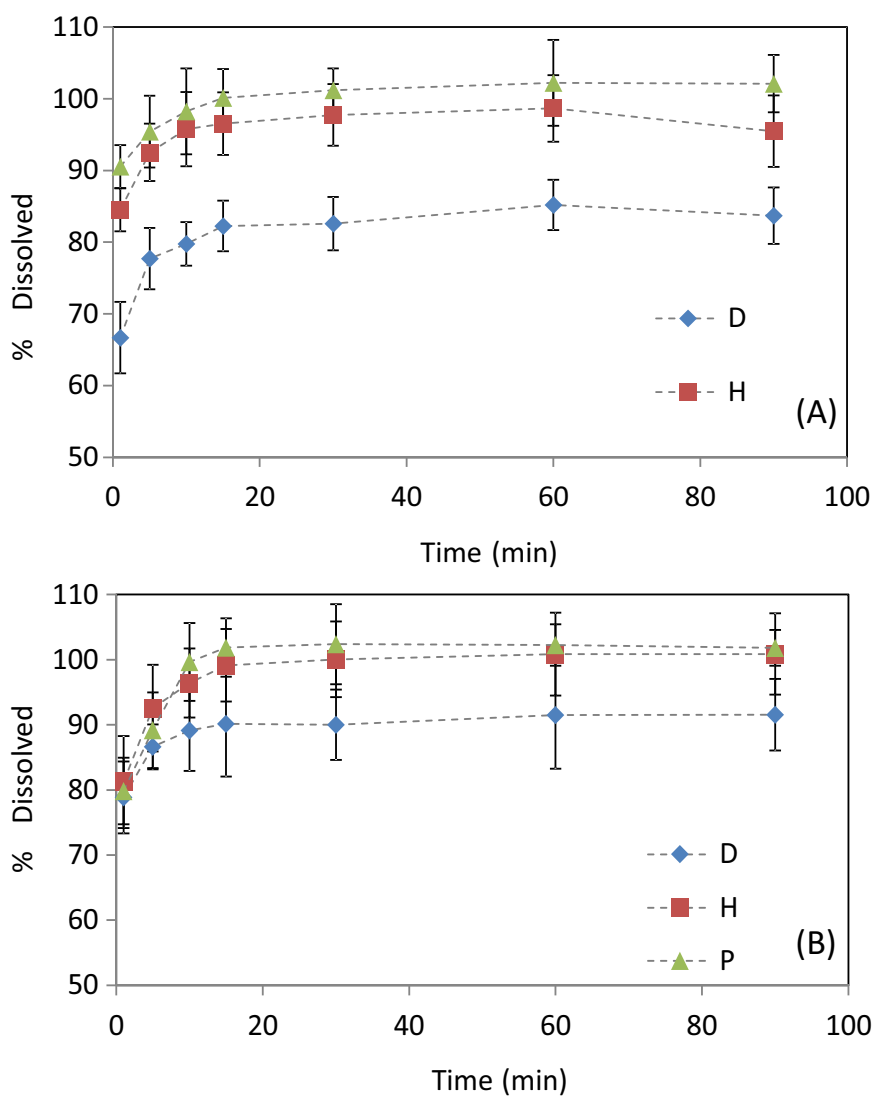

FIGURE 5 - Dissolution profiles of suspensions of SSZ (250 $\mathrm{mg} / 5 \mathrm{~mL}$ ) $\mathrm{mL}$ in phosphate buffer saline $\mathrm{pH} \mathrm{5.8}$, at rotations of $25 \mathrm{rpm}$ (A) and $50 \mathrm{rpm}$ (B). Mean and standard deviation of $\mathrm{n}=6$ determinations. 
polysorbate 80 was considerably better than in phosphate buffer $\mathrm{pH} 5.8$ alone, since the surfactant improved the average solubility of the drug in this medium, from $273 \mu \mathrm{g} / \mathrm{mL}$ to $725 \mu \mathrm{g} / \mathrm{mL}$ ( 2.6 times). As can be seen in Figure 6, the dissolution curves for the suspensions using rotation of $25 \mathrm{rpm}$ were similar. Figure $6 \mathrm{~A}$ shows a large and significant difference between suspensions $\mathrm{D}$ and $\mathrm{H}$ at the first time $(\mathrm{P}<0.0001)$ and between $\mathrm{D}$ and $\mathrm{P}$ for times of 1 and 10 minutes $(P<0.05)$. After these initial intervals, the dissolution of the suspensions was similar, reaching a plateau after 15 minutes. The significant difference at the start of dissolution between formulations $D$ versus $P$ and $D$ versus $H$ can be related to the low rotation speed, because the RSD obtained for formulation $\mathrm{D}$ at the first time was above $10 \%$. The dissolution profiles of the suspensions at $50 \mathrm{rpm}$ (Figure 6B) were similar, with no significant differences $(\mathrm{P}>0.05)$. The sink condition was attained at 6.5 times bellow the saturation concentration of the drug.
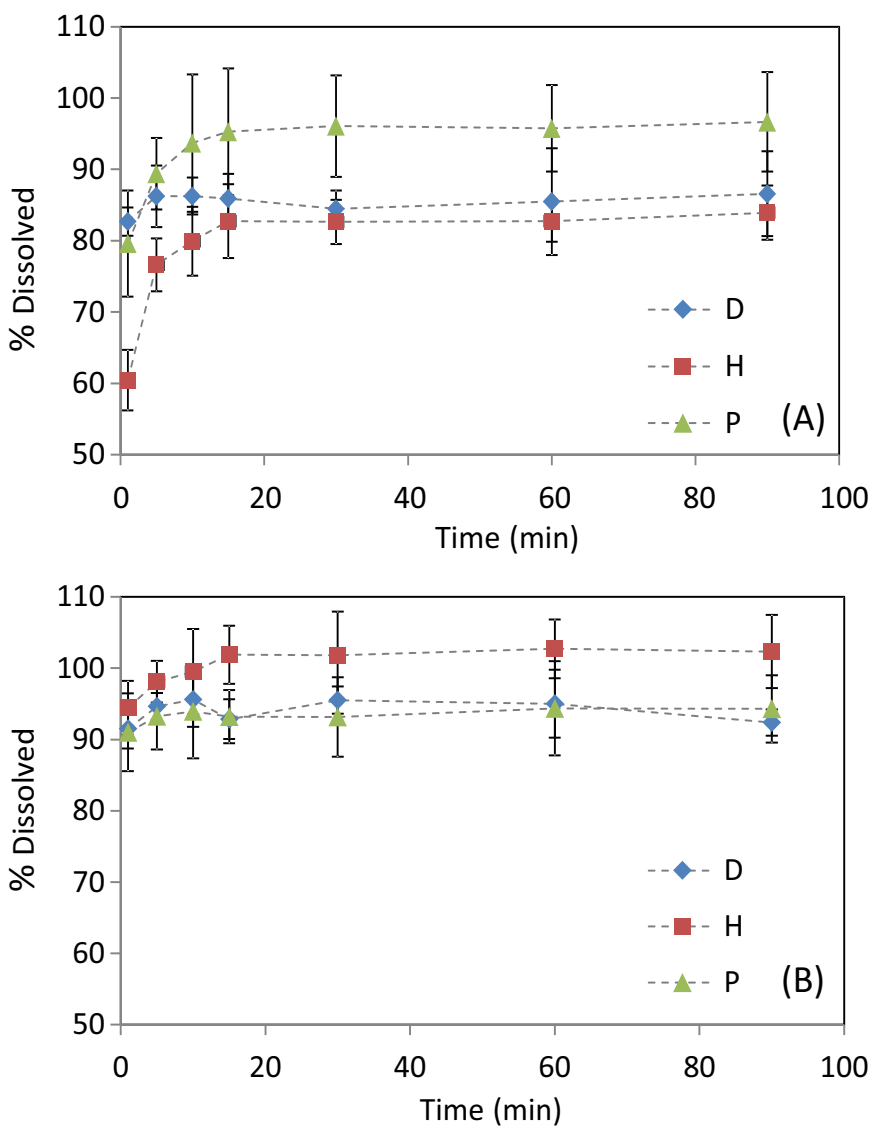

FIGURE 6 - Dissolution profiles of suspensions of SSZ $(250 \mathrm{mg} / 5 \mathrm{~mL}) \mathrm{mL}$ in phosphate buffer saline $\mathrm{pH} 5.8$ with $0.5 \%$ polysorbate 80 , at rotations of $25 \mathrm{rpm}$ (A) and $50 \mathrm{rpm}$ (B). Mean and standard deviation of $\mathrm{n}=6$ determinations.

In the phosphate buffer $\mathrm{pH} 6.8$ medium (Figure 7), all the suspensions reached dissolution levels above
$85 \%$ at rotations of 25 and $50 \mathrm{rpm}$ in 15 minutes. These suspensions can therefore be classified as immediate release formulations (ANVISA, 2010; Storpirtis et al., 2009; Manadas, Pina, Veiga, 2002). At 25 rpm (Figure 7A) there were significant differences $(\mathrm{P}<0.05)$ between formulation $\mathrm{D}$ and $\mathrm{H}$ and between $\mathrm{D}$ and $\mathrm{P}$ for the first dissolution times. However, as of 10 minutes the dissolution profiles did not present significant differences. At $50 \mathrm{rpm}$ the dissolution profiles of the suspensions did not differ significantly (Figure 7B).
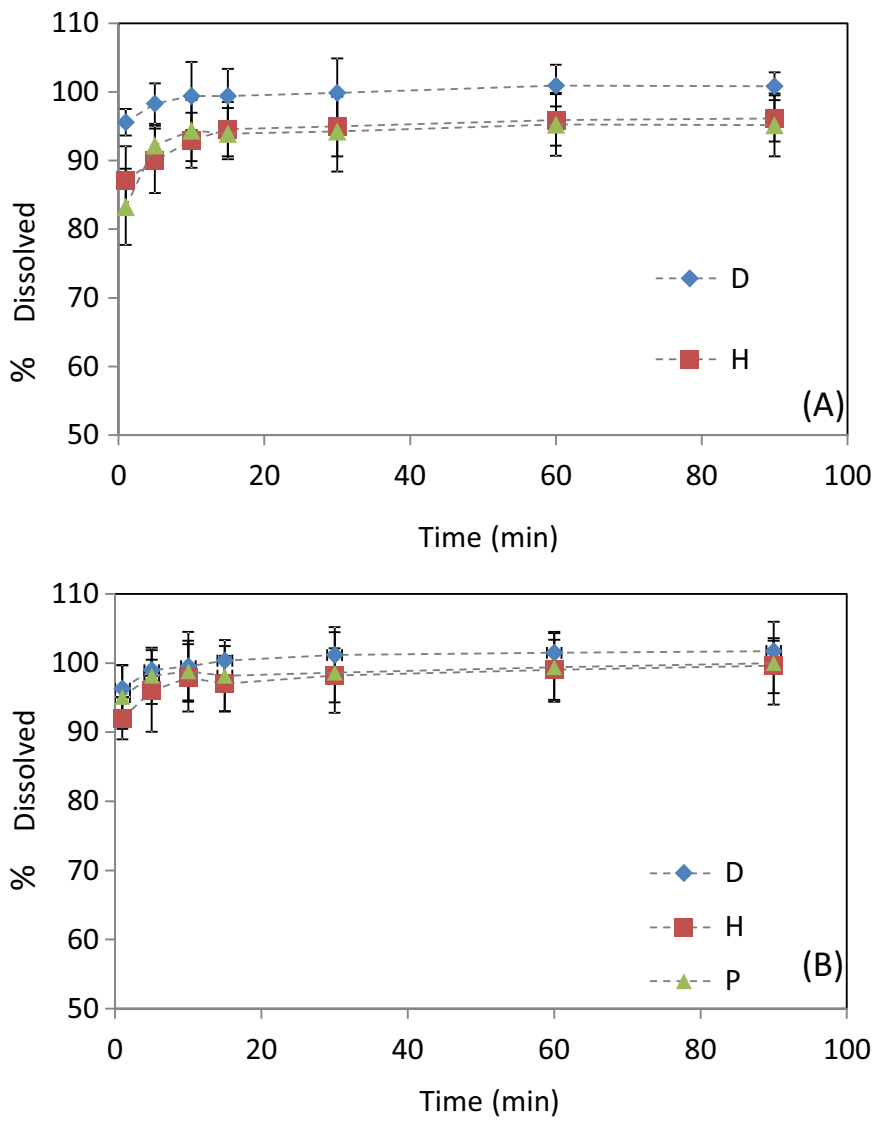

FIGURE 7 - Dissolution profiles of suspensions of SSZ $(250 \mathrm{mg} / 5 \mathrm{~mL}) \mathrm{mL}$ in phosphate buffer saline $\mathrm{pH} 6.8$, at rotations of $25 \mathrm{rpm}$ (A) and $50 \mathrm{rpm}$ (B). Mean and standard deviation of $\mathrm{n}=6$ determinations.

Figures $8 \mathrm{~A}$ and $\mathrm{B}$ show the dissolution profiles of the suspensions in $\mathrm{pH} 7.4$ buffer. In this medium, there was no significant difference $(\mathrm{P}>0.05)$ between the dissolution profiles of the formulations at the two rotation speeds used. In all cases, $100 \%$ dissolution was achieved in 15 minutes, characteristic of immediate release formulations.

The solubility study of the SSZ showed that the increase of $\mathrm{pH}$ caused an increase in the SSZ solubility. SSZ is a weak acid and presents partial ionization of the acid group. For weak acids when the $\mathrm{pH}$ of the medium 

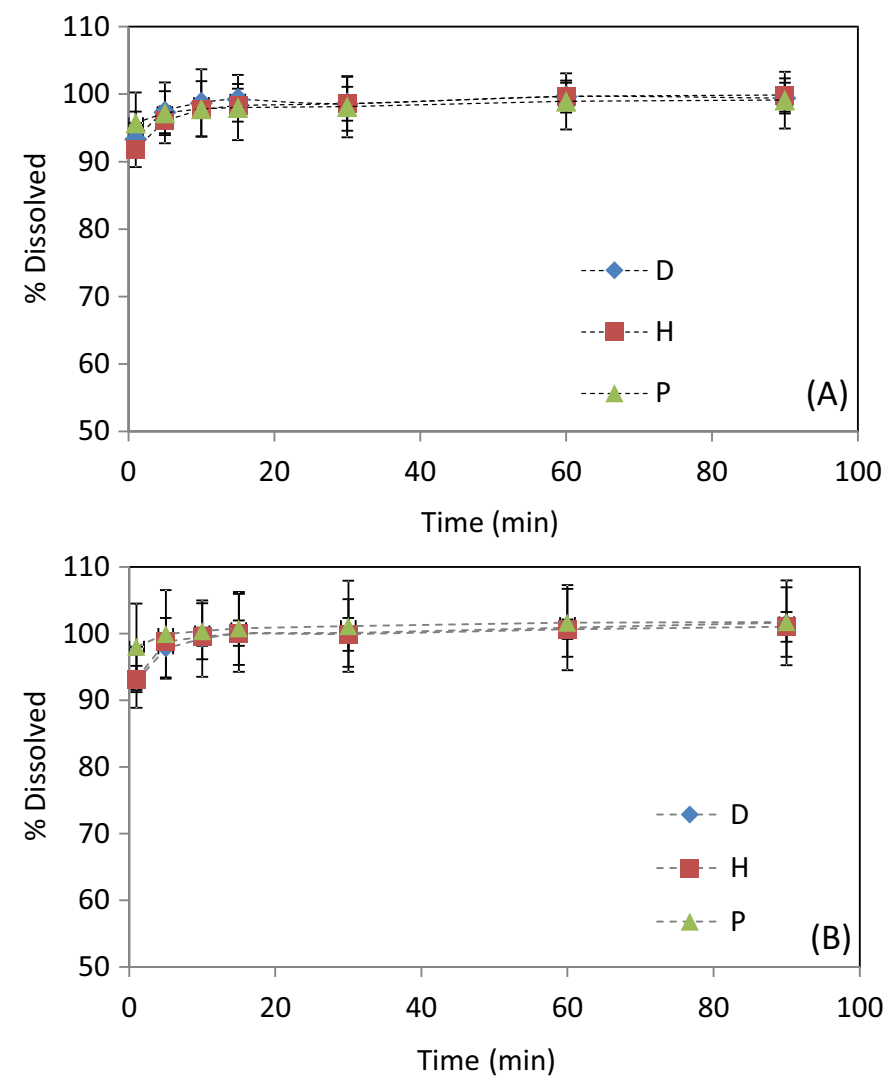

FIGURE 8 - Dissolution profiles of the suspension of sulfasalazine $250 \mathrm{mg} / 5 \mathrm{~mL}$ in phosphate buffer saline $\mathrm{pH}$ 7.4, at rotations of $25 \mathrm{rpm}$ (A) and $50 \mathrm{rpm}$ (B). Mean and standard deviation of $\mathrm{n}=6$ determinations.

increases, the solubility of the acid also increases due to the contribution of the ionized form (Horter; Dressman; 2001).

Sulfasalazine is a classic example of a prodrug. It undergoes cleavage of the diazo bond in the colon by the metabolic action of bacterial colonies, thus releasing 5-aminosalicylic acid (5-ASA) and sulfapyridine. This release process occurs in biological environments with $\mathrm{pH}$ between 5.5 and 7, conditions that exist in the cecum, colon and rectum. It is important for SSZ to dissolve completely in these sites to enable its metabolism. Therefore, the profiles found here indicate that in the suspension formulations studied, the drug will be available in soluble form during its passage through the large intestine, enabling its delivery to the action sites (Sinko, 2008; Santos Junior, 1999; Dahan, Amidon, 2010).

The result of the dissolution test of the Azulfin ${ }^{\circledR}$ tablet in gastric juice $(\mathrm{HCl} 0.1 \mathrm{~N}, \mathrm{pH} 1.2)$ was satisfactory, because the percentage of dissolved drug was less than $0.5 \%$. For the first stage (acid medium), the percentage of drug dissolved should not exceed 10\% (USP, 2011b). The results of the dissolution profile in PBS pH 7.4 are exhibited in the Figure 9. For the second stage, the percentage of drug dissolved should exceed $90 \%$ according to USP(2011b). The result was excellent, because percentage of dissolved drug was $104 \pm 2.1 \%$ at 90 minutes. However, the suspension showed SSZ dissolution percentage of $100 \%$ at 10 minutes in medium PBS pH 7.4 with at rotation of $50 \mathrm{rpm}$. Thus, the suspension exhibited faster dissolution rate than the tablet.

Due to the coating, the coated tablets exhibit slower dissolution than suspensions. The coating must be broken by aqueous dissolution medium to start the disintegration of the tablet core. Thus, the disintegration process promotes the drug dissolution. The suspensions are disperse systems and do not suffer disintegration. In this case, the drug particles in suspension suffer rapid dissolution after contact with the dissolution medium.

The SSZ suspensions are liquid formulations that facilitate swallowing and exhibit fast dissolution in comparison with reference formulation (Azulfin ${ }^{\circledR}$ tablet). However, the suspensions have some disadvantages in comparison with solid formulations. Suspensions usually suffer sedimentation and must be homogenized by stirring before use. Moreover, suspensions can exhibit unpleasant taste, however, this problem can be corrected with sweeteners and flavoring.

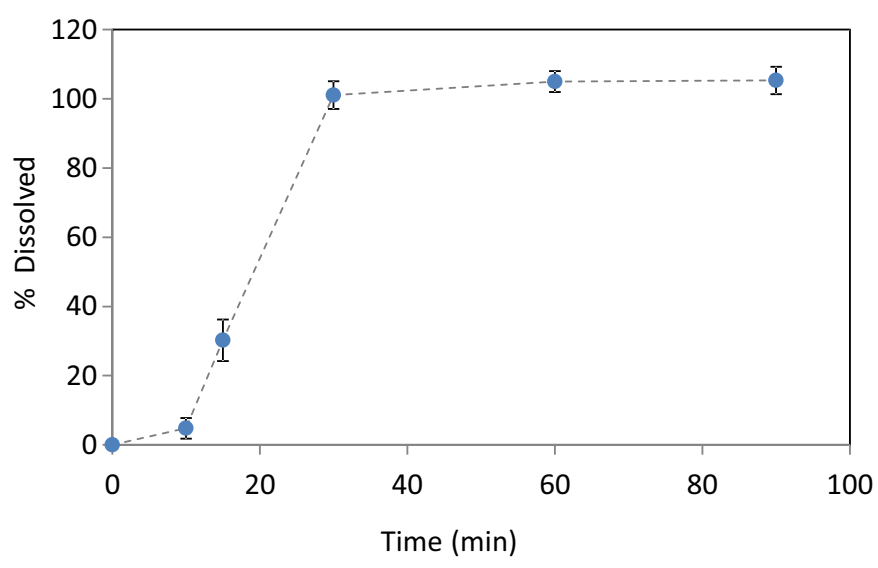

FIGURE 9. Dissolution profile of the Azulfin ${ }^{\circledR}$ tablets in phosphate buffer saline $\mathrm{pH} 7.4$, at rotation of $100 \mathrm{rpm}$. Mean and standard deviation of $n=6$ determinations.

\section{CONCLUSIONS}

Control of the particle size is important because this parameter can cause differences in the physical and chemical characteristics, such as solubility, viscosity and homogeneity of suspensions. Differences of solubility between SSZ-D, SSZ-H and SSZ-P, obtained from the three suppliers, were found in the dissolution media. This shows the importance of quality control in the 
supplier qualification. The suspension of sulfasalazine $250 \mathrm{mg} / 5 \mathrm{~mL}$ is a formulation that is easy to prepare, both by compounding pharmacies and mass manufacturers. The dissolution study of the suspensions showed that the formulations presented very fast dissolution rates, with levels higher than $85 \%$ in 20 minutes in the phosphate buffer $\mathrm{pH} 5.8$, phosphate buffer $\mathrm{pH} 5.8$ with $0.5 \%$ polysorbate 80 , phosphate buffer $\mathrm{pH} 6.8$ and phosphate buffer $\mathrm{pH} 7.4$ media, at a rotation speed of $50 \mathrm{rpm}$. The SSZ samples obtained from the three suppliers (D, H and P) presented similar dissolution profiles, since there were no significant differences between them $(\mathrm{P}>0.05)$ in the same four media at rotation of $50 \mathrm{rpm}$. The rotation speed of $50 \mathrm{rpm}$ is the most suitable for the dissolution studies of the suspensions. The sulfasalazine $250 \mathrm{mg} / 5 \mathrm{~mL}$ suspension dissolved rapidly and is a promising formulation for clinical use to treat chronic intestinal inflammatory diseases, especially for administration to newborns, young children and the elderly. The liquid formulation is more flexible regarding administration and dosage adjustment than the solid form.

\section{REFERENCES}

AGÊNCIA NACIONAL DE VIGILÂNCIA SANITÁRIA. Resolução Diretoria Colegiada (RDC) n ${ }^{\circ} 31,11$ agosto 2010. Dispõe sobre estudos de equivalência farmacêutica e de perfil de dissolução comparativo. Diário Oficial da União, Brasília, 12 ago 2010. Disponível em: Available at $<$ http://e-legis.anvisa.gov.br>. Acesso em: 12 jun. 2014.

CLARYSSE, S.; BROUWERS, J.; TACK, J.; ANNAERT, P.; AUGUSTIJINS, P.Intestinal drug solubility estimation based on simulated intestinal fluids: Comparison with solubility in human intestinal fluids. Eur. J. Pharm.Sci., v.43, n.4, p.260-269, 2011.

COSTA, M.A.B.; RICCI-JÚNIOR, E.; MANSUR, C.R.E.; CAMPOS, V.EB.; SANTOS, E.P. Development and validation of analytical method for determination of sulfasalazine in oral suspension: comparison between spectroscopic and high performance liquid. Quim. Nova, v.35, n.4, p.808-813, 2012.

DAHAN, A,; AMIDON, G.L. MRP2 mediated drugdrug interaction: Indomethacin increases sulfasalazine absorption in the small intestine, potentially decreasing its colonic targeting. Int. J. Pharm., v.386, n.1-2, p.216-20, 2010.
GENC, H.; CAKIT, B.D.; NACIR, B.; SARACOGLU, M.; KACAR, M.; ERDEM, H.R. The effects of Sulfasalazine treatment on enteral abnormalities of inflammatory rheumatic diseases. Clin. Rheumatol., v.26, n.7, p.11041110, 2007.

HANSON, R.; GRAY, V.Handbook of dissolution testing. Hockessin, Del: Dissolution Techonologies, 2004. 199 p.

HORTER, D.; DRESSMAN, J.B. Influence of physicochemical properties on dissolution drugs in the gastrointestinal tract. Adv. Drug Delivery Rev. v. 46, n.1-3, p.75-87, 2001.

KUMAGAI, S.; KOMADA, F.; KITA, T.; MORINOBU, A.; OZAKI, S.; ISHIDA, H.; SANO, H.; MATSUBARA, T.; OKUMURA, K. N-Acetyltransferase 2 Genotype-Related Efficacy of Sulfasalazine in Patients with Rheumatoid Arthritis. Pharm. Res. v. 21, n.2, p.324-329, 2004.

MANADAS, R.; PINA, M.E.; VEIGA, F. A dissolução in vitro na previsão da absorção oral de fármacos em formas farmacêuticas de liberação modificada. Braz. J. Pharm. Sci. v. 38, n. 4, p. 375-399, 2002.

MILANI-ZAKERI, P.; BARZEGAR-JALALI, M.; AZIMI, M.; VALIZADEH, H. Biopharmaceutical classification of drugs using intrinsic dissolution rate (IDR) and rat intestinal permeability. Eur. J. Pharm. Biopharm., v.73, n.1, p.102106, 2009.

MOFFAT, C.A.; OSSELTON M. D.; WIDDOP, B. Clarke's Analysis drugs and poison. 3.ed. London; Chicago: Pharmaceutical Press, 2004. v. 2.

PRISTA, L.N.; ALVES, A.C.; MORGADO, R.M.R. Tecnologia farmacêutica. 7.ed. Lisboa: Calouste Gulbenkian., 2008. v. 1, p.683-732.

SANTOS JUNIOR, J.C.M. Doença intestinal inflamatória, retocolite ulcerativa II. Rev. Bras. Colo-proctol., v.19, p.29-34, 1999

SIEWERT, M.; DRESSMAN, J.; BROWN, C.K.; SHAH, v.P. Guidelines to dissolution/in Vitro Release Testing of Novel/ Special Dosage Forms. AAPS PharmSciTech. v. 4, n.1, p.1-10, 2003.

SINKO, p.J. Físico-farmácia e ciências Farmacêuticas. Porto Alegre: Artmed, 2008. 809 p. 
SKOOG, D.A.; HOLLER, F.J.; CROUCH, S.R. Princípios de análise instrumental. Porto Alegre: Artmed, 2007. 1055 p.

STORPIRTIS, S.; GONÇALVES, J. E.; CHIANN, C.; GAI, M.N. Biofarmacotécnica. Rio de Janeiro: Guanabara Koogan, 2009. 316 p.

TRINCHES, R.C.; SAEGER, S.C.; PEREIRA, S.N.; BARROS, R.C.; CHIAVEGATTO, L.F.; LIMA, L.M.T. Desenvolvimento e estabilidade de suspensões de sulfassalazina em xarope. Int. J. Pharm. Comp., v.6, n.4, p.198-201, 2004.
UNITED STATES PHARMACOPEIA USP. Official monographs: validation of compendial methods. 34 . ed. Rockville: United States Pharmacopeial Convention, 2011a. chap.1225, p.964-965.

UNITED STATES PHARMACOPEIA USP. Official monographs: validation of compendial methods. 34.ed. Rockville: United States Pharmacopeial Convention, 2011b. p. 4309 .

Received for publication on $02^{\text {nd }}$ July 2014 Accepted for publication on $02^{\text {nd }}$ November 2014 
